\title{
Persistence of a clone of methicillin-resistant Staphylococcus aureus in a burns unit
}

\author{
A. M. AL-HADDAD, E. E. UDO*, E. M. MOKADAS*, S. C. SANYAL* and W. B. GRUBB \\ School of Biomedical Sciences, Curtin University of Technology, Perth, Western Australia and *Department of \\ Microbiology, Faculty of Medicine, Kuwait University, PO Box 24923, Safat 13110, Kuwait
}

\begin{abstract}
A total of 128 MRSA isolates from a burns unit in 1992 and 1997 was studied by resistotyping, plasmid analysis and pulsed-field gel electrophoresis (PFGE) of SmaIdigested chromosomal DNA to ascertain whether a clone of MRSA had persisted in the unit or whether different clones had been introduced at different times. All the MRSA isolates produced $\beta$-lactamase and had high MICs to methicillin $(>256 \mathrm{mg} / \mathrm{L})$. All were resistant to tetracycline, kanamycin, cadmium acetate and mercuric chloride. Most were resistant to gentamicin, neomycin, erythromycin, chloramphenicol, trimethoprim, ciprofloxacin, propamidine isethionate and ethidium bromide, and were susceptible to minocycline, vancomycin and teicoplanin. None of the 1992 isolates was resistant to mupirocin, but $56 \%$ and $19 \%$ of the 1997 isolates expressed high- and low-level mupirocin resistance, respectively. Many of the 1997 isolates had acquired a 38-kb plasmid encoding high-level mupirocin resistance. The 1992 isolates had two main PFGE patterns; 82\% of them belonged to PFGE pattern 1. The 1997 isolates had PFGE pattern 1, the same as the majority of the 1992 isolates. All MRSA isolates from both years carried the mecA gene in the same $S m a I$ fragment. These findings demonstrated that a clone of MRSA that was prevalent in the burns unit in 1992 had persisted and became the predominant clone in 1997.
\end{abstract}

\section{Introduction}

Following the initial isolation of methicillin-resistant Staphylococcus aureus (MRSA) in the UK in 1961, many outbreaks of infections due to MRSA have occurred and it has now become endemic in several centres throughout the world [1,2]. MRSA was associated initially with large teaching hospitals, but has now also been found in nursing homes and in the community [3]. MRSA strains are often resistant to a wide range of antimicrobial agents including $\beta$-lactam agents, tetracylines, macrolides, lincosamides, aminoglycosides, quinolones, heavy metals, disinfectants and antiseptics [3,4]. They are also efficient colonisers of patients' noses and the hospital environment. Some of them may spread readily within and between hospitals. The spread of those strains, referred to as epidemic MRSA (EMRSA) [2,3], is of particular concern because of the difficulty in eradicating them once they

Received 12 June 2000; revised version received 8 Nov. 2000; accepted 16 Nov. 2000.

Corresponding author: Dr E. E. Udo (e-mail: EDET@hsc. kuniv.edu.kw). are established in a unit, plus the reduction in therapeutic options and the high cost of treating infections caused by them [5].

To control the spread of MRSA strains, it is often necessary to type them to understand their epidemiology and ascertain whether the spread is due to a single or multiple clones $[6,7]$. Several molecular epidemiological techniques have been used to type MRSA isolates. These include plasmid profile [8], restriction fragment-length polymorphism (RFLP) of plasmids $[6,9]$, pulsed-field gel electrophoresis (PFGE) of Sma I-digested chromosomal DNA $[10,11]$ and Southern hybridisation with various probes [12]. A combination of different methods can provide good strain discrimination $[6,7,13]$.

The burns unit at the Ibn Sina Hospital, Kuwait, is a 70-bed special facility for treating patients with burn injuries for the whole of Kuwait. It has an intensive care unit with 12 beds. The bed occupancy in the burns unit is $70-100 \%$. Although it is not certain when MRSA was first isolated in the burns unit, it has been isolated consistently since 1992 and is considered to be endemic in the unit. Recently, MRSA isolates from the 
unit have been found to have acquired high-level mupirocin resistance [14]. The mupirocin-resistant isolates were found to be related to mupirocinsusceptible ones, indicating that MRSA already present in the unit had acquired the mupirocin resistance gene. However, the study covered only recent isolates. This study sought to determine whether the MRSA strains isolated recently in the unit were related to those isolated in the past.

\section{Materials and methods}

\section{MRSA isolates}

The isolates examined consisted of 96 MRSA isolates collected in 1992 and 32 isolates collected in 1997 from the burns unit, Ibn Sina Hospital, Kuwait. They were single patient isolates and were from different clinical specimens. The 1997 isolates were obtained from individual patients between January and June of that year. They were identified by cultural characteristics, growth on mannitol salt agar, Gram's stain and coagulase positivity. MRSA isolates were preserved at $-80^{\circ} \mathrm{C}$ in glycerol $15 \%$. They were subcultured in Brain Heart Infusion Broth (BHIB) and on BHI Agar (Oxoid) when required.

\section{Determination of $\mathrm{MIC}$}

The MIC of methicillin for all MRSA isolates was determined by an agar incorporation method with Mueller-Hinton agar plates containing concentrations of methicillin (Sigma) from 0.25 to $256 \mathrm{mg} / \mathrm{L}$. The test was incubated at $30^{\circ} \mathrm{C}$ for $24 \mathrm{~h}$. The MIC was taken as the highest dilution of the antibiotic that inhibited growth. S. aureus strains ATCC 29213 (MIC 0.5$2 \mathrm{mg} / \mathrm{L}$ ) and WBG525 (MIC >256 mg/L), an Eastern Australian MRSA [15], were used as controls in the test.

\section{Detection of $\beta$-lactamase production}

$\beta$-lactamase production was detected with the chromogenic cephalosporin (nitrocefin; Oxoid) according to the manufacturer's instructions. Nitrocefin solution $(5 \mu \mathrm{l})$ was dropped on a single colony of an overnight culture. Development of a red colour within $1 \mathrm{~min}$ indicated a positive result. Positive (strain WBG525) and negative (strain WBG248) controls [15] were tested in parallel.

\section{Susceptibility to antimicrobial agents}

Susceptibility to antimicrobial agents was determined by standard disk diffusion tests on Mueller-Hinton Agar (Mast Diagnostics, Merseyside). The following antibiotic disks (Oxoid) were used: methicillin (Mc, $5 \mu \mathrm{g})$, penicillin $\mathrm{G}(\mathrm{Pc}, 2 \mathrm{U})$, gentamicin $(\mathrm{Gm}, 10 \mu \mathrm{g})$, kanamycin $(\mathrm{Km}, 30 \mu \mathrm{g})$, neomycin $(\mathrm{Nm}, 30 \mu \mathrm{g})$, streptomycin (Sm, $10 \mu \mathrm{g})$, tobramycin (Tm, $10 \mu \mathrm{g})$, chloramphenicol $(\mathrm{Cm}, 30 \mu \mathrm{g})$, tetracycline (Tc, $30 \mu \mathrm{g})$, minocycline $(\mathrm{Mn}, 30 \mu \mathrm{g})$, erythromycin (Em, $15 \mu \mathrm{g}$ ) clindamycin $(\mathrm{Cl}, 2 \mu \mathrm{g})$ rifampin (Rf, $30 \mu \mathrm{g})$, fusidic acid (Fa, $10 \mu \mathrm{g})$, novobiocin ( $\mathrm{Nv}, 10 \mu \mathrm{g}$ ), trimethoprim (Tp, $5 \mu \mathrm{g}$ ), vancomycin (Va, $30 \mu \mathrm{g}$ ), teicoplanin (Tec, $30 \mu \mathrm{g}$ ) and mupirocin (Mup, 200 and $5 \mu \mathrm{g}$ ). Disks containing heavy metals and disinfectants were prepared in the laboratory with the following concentrations $(10 \mu \mathrm{l})$ : mercuric chloride, $109 \mu \mathrm{g}$; cadmium acetate, $54 \mu \mathrm{g}$; propamidine isethionate, $100 \mu \mathrm{g}$ and ethidium bromide, $59 \mu \mathrm{g}$.

\section{Preparation of plasmid DNA}

Plasmids were isolated by the cetyltrimethylammonium bromide method as described previously [16]. Electrophoresis was performed in agarose (Boehringer, Mannheim GmbH, Germany) $0.6 \% \mathrm{w} / \mathrm{v}$ in TAE buffer (40 mM Tris, $20 \mathrm{mM}$ sodium acetate, $1 \mathrm{mM}$ EDTA) at $25 \mathrm{~V}$ for $16 \mathrm{~h}$. The mol. wt of plasmids was determined by comparing their migration with plasmids in strain WBG4483 [17] which contains four plasmids of 40.3, 22.5, 4.4 and $3.5 \mathrm{~kb}$. Plasmids were digested by EcoRI restriction endonuclease according to the manufacturer's instructions (Gibco BRL).

\section{Curing of resistance at $43.5^{\circ} \mathrm{C}$}

Curing experiments were performed as described previously [17]. Briefly, cultures were grown on BHIA at $43^{\circ} \mathrm{C}$ for $48 \mathrm{~h}$ and single colonies were screened for loss of resistance to antimicrobial agents by replica plating. Disk diffusion tests were performed on strains to confirm loss of resistance. Plasmid loss was confirmed by agarose gel electrophoresis.

\section{Plasmid transfer}

Mixed-culture transfer (MCT) and conjugation experiments with strains WBG1876 and WBG541 as recipients, respectively, were performed as described previously [17]. Selections were made on BHIA containing (mg/L) fusidic acid (5) and rifampin (2.5) and one of the following: tetracycline (5), erythromycin (5), gentamicin (8), chloramphenicol (10), trimethoprim (5), mupirocin (5), cadmium acetate (60) or propamidine isethionate (100). Transcipients or transconjugants were screened for plasmid carriage by agarose gel electrophoresis.

\section{Chromosomal DNA isolation}

Chromosomal DNA was isolated as described previously [10]. The blocks were treated with SmaI restriction endonuclease (New England Biolab) according to the manufacturer's instructions.

\section{PFGE of chromosomal DNA}

Contour-clamped homogeneous electric field (CHEF) electrophoresis of SmaI-digested DNA was performed 
in agarose (pulsed-field certified agarose, BioRad, USA) $1 \%$ and the CHEF-DRIII system (BioRad) at $14^{\circ} \mathrm{C}$ and $6 \mathrm{~V} / \mathrm{cm}$ for $20 \mathrm{~h}$ in $0.5 \times \mathrm{TBE}$ (45 mM Tris, $45 \mathrm{~mm}$ boric acid, $1 \mathrm{~mm}$ EDTA). The pulse times were $5 \mathrm{~s}$ initial and $40 \mathrm{~s}$ final. A $\lambda$ DNA concatemer (BioRad) was used as a molecular size marker. After electrophoresis, the gel was stained in ethidium bromide $0.5 \mu \mathrm{g} / \mathrm{ml}$ and photographed under ultraviolet illumination. The chromosomal patterns were examined by eye and assigned to PFGE types.

\section{MecA PCR}

DNA extraction for PCR amplification of the mecA gene was performed as described previously [18]. PCR was performed as follows: $45 \mu \mathrm{l}$ of supermix (Gibco BRL), containing $22 \mathrm{mM}$ Tris- $\mathrm{HCl}(\mathrm{pH} 8.4), 55 \mathrm{mM}$ $\mathrm{KCl}, 1.65 \mathrm{mM} \mathrm{MgC1} 1_{2}, 220 \mu \mathrm{M}$ dGTP, $220 \mu \mathrm{M}$ dATP, $220 \mu \mathrm{M}$ dTTP, $220 \mu \mathrm{M}$ dCTP, recombinant Taq DNA polymerase $22 \mathrm{U}, 10 \mathrm{pmol}$ each of two primers and template DNA $3 \mu \mathrm{l}$. Synthetic oligonucleotides used as primers were mecAl forward: 5'-AAAATCGATGG TAAAGGTTGGC-3' complementary to nucleotides 1282-1303, and mecA2 5'-AGTTCTGCAGTACCG GATTTGC-3' complementary to nucleotides 17931814. Temperature cycling for the PCR experiments was accomplished in a DNA Thermal Cycler (Perkin Elmer, Gene Amp, PCR 9600). Cycling parameters were as follows: 1 cycle of $94^{\circ} \mathrm{C}$ for $1 \mathrm{~min}, 55^{\circ} \mathrm{C}$ for $30 \mathrm{~s}, 72^{\circ} \mathrm{C}$ for $90 \mathrm{~s}$ followed by 30 cycles of $94^{\circ} \mathrm{C}$ for $1 \mathrm{~min}, 55^{\circ} \mathrm{C}$ for $30 \mathrm{~s}, 72^{\circ} \mathrm{C}$ for $90 \mathrm{~s}$. At the end of amplification, the amplified product was visualised by subjecting $10 \mu \mathrm{l}$ of the reaction volume to agarose gel electrophoresis in agarose $1 \%$ and staining with ethidium bromide $0.5 \mu \mathrm{g} / \mathrm{ml}$.

\section{DNA-DNA hybridisation}

DNA fragments separated by PFGE were transferred by Southern blotting to a positively charged nylon membrane (Boehringer Mannheim) under standard conditions [19]. The amplified mecA DNA (533 bp) was labelled with digoxigenin-dUTP with the Random Primer DNA Labelling Kit (Boehringer Mannheim) and used to probe DNA fragments. Hybridisation and posthybridisation washes and detection with the chemiluminescent substrate CDP Star (Boehringer Mannheim) were performed according to methods provided by the manufacturer. Autoradiographs were obtained with Kodak X-OMAT film after incubation for $15 \mathrm{~min}$ at room temperature.

\section{Results}

\section{Characteristics of MRSA isolates}

All 128 isolates had MIC values for methicillin $>256 \mathrm{mg} / \mathrm{L}$. Methicillin resistance was confirmed by detection of the mecA gene in PCR experiments. All isolates gave an amplified product of $533 \mathrm{bp}$. All isolates produced $\beta$-lactamase and were resistant to various antimicrobial agents as presented in Table 1. The isolates from both periods were all resistant to tetracyline, kanamycin, cadmium acetate and mercuric chloride. There was an increase in the incidence of resistance to ciprofloxacin from $61 \%$ in the 1992 isolates to $90 \%$ in the 1997 isolates.

Also, 56\% and 19\% of the 1997 isolates expressed high- and low-level mupirocin resistance, respectively, whereas none of the 1992 isolates was resistant to mupirocin. All the isolates in both periods were sensitive to minocycline, vancomycin and teicoplanin.

\section{Plasmid analysis}

MRSA isolates from both 1992 and 1997 were grouped into 15 plasmid patterns as shown in Table 2. They harboured one-to-five plasmids, which varied in size from 1.9 to $38 \mathrm{~kb}$. Eight plasmid profiles were detected

Table 1. Antimicrobial resistance of MRSA isolates in 1992 and 1997

\begin{tabular}{|c|c|c|}
\hline Antibiotic & $\begin{array}{l}\text { Number }(\%) \text { of resistant } \\
\text { strains in } 1992(n=96)\end{array}$ & $\begin{array}{l}\text { Number }(\%) \text { of resistant } \\
\text { strains in } 1997(n=32)\end{array}$ \\
\hline Tetracycline & $96(100)$ & $32(100)$ \\
\hline Gentamicin & $85(89)$ & $32(100)$ \\
\hline Kanamycin & $96(100)$ & $32(100)$ \\
\hline Neomycin & $90(94)$ & $25(78)$ \\
\hline Tobramycin & $59(61)$ & $30(94)$ \\
\hline Streptomycin & $94(98)$ & $22(69)$ \\
\hline Chlorampenicol & $83(86)$ & $25(78)$ \\
\hline Trimethoprim & $96(100)$ & $28(88)$ \\
\hline Ciprofloxacin & $61(64)$ & $29(91)$ \\
\hline Erythromycin & $88(92)$ & $29(91)$ \\
\hline Clindamycin & $9(9)$ & $3(9)$ \\
\hline Propamidine isethionate & $88(92)$ & $32(100)$ \\
\hline Ethidium bromide & $88(92)$ & $32(100)$ \\
\hline Cadmium acetate & $96(100)$ & $32(100)$ \\
\hline Mercuric chloride & $96(100)$ & $32(100)$ \\
\hline Mupirocin (high resistance) & $0(0)$ & $18(56)$ \\
\hline Mupirocin (low resistance) & $0(0)$ & $6(19)$ \\
\hline Minocycline & $0(0)$ & $0(0)$ \\
\hline Vancomycin & $0(0)$ & $0(0)$ \\
\hline Teicoplanin & $0(0)$ & $0(0)$ \\
\hline
\end{tabular}


Table 2. Plasmid profiles of MRSA in 1992 and 1997

\begin{tabular}{lccc}
\hline $\begin{array}{l}\text { Plasmid } \\
\text { profile }\end{array}$ & Plasmid size, $(\mathrm{kb})$ & $\begin{array}{c}\text { Number }(\%) \text { of isolates } \\
\text { in } 1992(\mathrm{n}=96)\end{array}$ & $\begin{array}{c}\text { Number }(\%) \text { of isolates } \\
\text { in } 1997(\mathrm{n}=32)\end{array}$ \\
\hline 1 & $27,3.4,2.9$ & $55(57.2)$ & $1(3)$ \\
2 & $27,3.4$ & $12(13)$ & $2(6)$ \\
3 & $15.2,3.4$ & $9(9)$ & $0(0)$ \\
4 & $30,27,3.4,2.9$ & $5(5)$ & $0(0)$ \\
5 & $30,3.4,2.9$ & $7(7)$ & $0(0)$ \\
6 & 3.4 & $4(4)$ & $0(0)$ \\
7 & $3.4,2.9$ & $3(3)$ & $0(0)$ \\
8 & $30,27,3.4$ & $1(1)$ & $0(0)$ \\
9 & $38,4.4,3.4,2.9$ & $0(0)$ & $42(38)$ \\
10 & $38,27,3.4$ & $0(0)$ & $5(13)$ \\
11 & $27,4.4,3.4$ & $0(0)$ & $2(6)$ \\
12 & $27,4.4,3.4,2.9$ & $0(0)$ & $2(6)$ \\
13 & $38,27,4.4,3.4$ & $0(0)$ & $2(6)$ \\
14 & $27,3.4,1.9$ & $0(0)$ & $2(6)$ \\
15 & $27,3.4,2.5$ & $0(0)$ & \\
\hline
\end{tabular}

in the 1992 isolates, with the type-1 profile being the dominant type. It represented $55(57 \%)$ of the 96 isolates and contained three plasmids of 27, 3.4 and $2.9 \mathrm{~kb}$ (Fig. 1). Twelve isolates (12.5\%) had the type-2 plasmid profile (27 and $3.4 \mathrm{~kb}$ ), and nine isolates $(9 \%)$ belonged to plasmid profile type 3 , in which the isolates had a unique $15.2-\mathrm{kb}$ plasmid in addition to the 3.4-kb plasmid. The remaining plasmid patterns, 4, 5, 6,7 and 8 were less frequent and they constituted $5 \%$, $7 \%, 4 \%, 3 \%$ and $1 \%$, respectively.

Nine plasmid patterns were identified in the 1997 isolates, and $38 \%$ of the isolates were of plasmid profile type 9. These had five plasmids of 38, 27, 4.4, 3.4 and $2.9 \mathrm{~kb}$ (Fig. 1). Plasmid profile type 9 was similar to profile type 1 except that the former had acquired the 38 - and 4.4-kb plasmids. Plasmid profiles 10 and 11 constituted $13 \%$ and $16 \%$, respectively. Plasmid profiles $12,13,14$ and 15 each constituted $6 \%$ of the total isolates examined. Isolates with plasmid profiles 3-8 which were found in 1992 were not

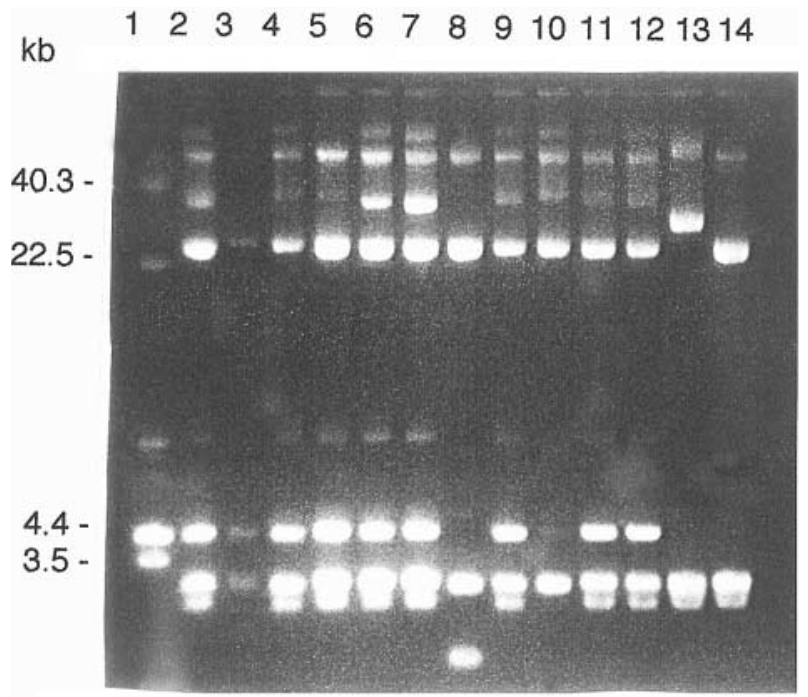

Fig. 1. Plasmid content of isolates. Lane 1, WBG4483 as size marker $(\mathrm{kb}) ; \mathbf{2}, \mathbf{4 - 7}, \mathbf{9}, \mathbf{1 1}, \mathbf{1 2}$, plasmid profile 9; 8 , plasmid profile $14 ; \mathbf{1 0}$, plasmid profile $10 ; \mathbf{1 3}$, plasmid profile $5 ; 14$, plasmid profile 1. detected in the 1997 isolates. Similarly, isolates with plasmid profiles 9-15 were present only in 1997. The 1997 isolates also lacked a 30-kb plasmid that was present in some of the 1992 isolates. None of the 1992 isolates contained the 38 - and $4.4-\mathrm{kb}$ plasmids that were present in the 1997 isolates.

\section{Curing of resistance determinants}

Curing experiments were performed on seven representative isolates from 1992 and 1997 that had different plasmid profiles. No loss of resistance was detected in two isolates from 1992, IBS105 and IBS82, which had plasmid profile types 2 and 4, respectively. However, in strain IBS6, with plasmid profile type 1, the loss of resistance to propamidine isethionate, ethidium bromide, cadmium acetate and mercuric chloride was accompanied by the loss of a $27-\mathrm{kb}$ plasmid. Resistance to propamidine isethionate and ethidium bromide were lost in isolates IBS18 and IBS107 (plasmid profile type 3 ) and the loss was accompanied by the loss of $15.2-\mathrm{kb}$ plasmids. In strain IBS115 (plasmid profile type 5), the loss of resistance to gentamicin, propamidine isethionate, ethidium bromide, cadmium acetate and mercuric chloride was accompanied by the loss of a 30-kb plasmid. Strain IBS240, isolated in 1997 and with plasmid profile 9 , had lost resistance to mupirocin together with chloramphenicol. The loss was accompanied by the loss of both 38 - and $4.4-\mathrm{kb}$ plasmids.

\section{Transfer of resistance and plasmids}

Ten isolates from 1992 and five isolates from 1997 were selected on the basis of their different plasmid profiles and used as donors in MCT and conjugation experiments. MCT was performed on seven and four isolates from 1992 and 1997, respectively. Transfer of resistance was obtained with five isolates (Table 3) and not with six (IBS18, IBS82, IBS105, IBS115 of the 1992 isolates and IBS239 and IBS281 of the 1997 isolates). A $27-\mathrm{kb}$ plasmid was transferred from strains IBS6 and IBS268, isolated in 1992 and 1997, respectively. They both transferred resistance to pro- 
Table 3. Mixed-culture transfer of resistance and plasmids to strain WBG1876

\begin{tabular}{lllc}
\hline Donor & Selection & Resistance transferred & Plasmids (kb) \\
\hline IBS6 & $\mathrm{Pi}$ & $\mathrm{Pi}, \mathrm{Eb}, \mathrm{Cd}, \mathrm{Hg}$ & 27 \\
IBS268 & $\mathrm{Pi}$ & $\mathrm{Pi}, \mathrm{Eb}, \mathrm{Cd}, \mathrm{Hg}$ & 27 \\
IBS73 & $\mathrm{Pi}$ & $\mathrm{Pi}, \mathrm{Eb}, \mathrm{Cd}, \mathrm{Hg}, \mathrm{Pc}$ & 30 \\
IBS107 & $\mathrm{Pi}$ & $\mathrm{Pi}, \mathrm{Eb}$ & 15.2 \\
IBS240 & $\mathrm{Mup}$ & $\mathrm{Mup}$ & 38 \\
& $\mathrm{Cm}$ & $\mathrm{Cm}$ & 4.4 \\
\hline
\end{tabular}

$\mathrm{Pi}$, propamidine isethionate; $\mathrm{Eb}$, ethidium bromide; $\mathrm{Cd}$, cadmium acetate; $\mathrm{Hg}$, mercury chloride; $\mathrm{Pc}$, penicillin; Mup, mupirocin; $\mathrm{Cm}$, chloramphenicol.

pamidine isethionate, ethidium bromide, cadmium acetate and mercuric chloride. Isolate IBS73, isolated in 1992, transferred a $30-\mathrm{kb}$ plasmid together with resistance to penicillin, propamidine isethionate, ethidium bromide, cadmium acetate and mercuric chloride. Also, isolate IBS107, isolated in 1992, transferred resistance to propamidine isethionate and ethidium bromide together with a $15.2-\mathrm{kb}$ plasmid. A $38-\mathrm{kb}$ plasmid was transferred together with high-level mupirocin resistance from isolate IBS240 in the MCT experiment.

Conjugation experiments were performed on four isolates. No plasmid transfer was obtained from three of the 1992 isolates. However, mupirocin resistance was transferred at high frequency from strain IBS240 isolated in 1997. This was accompanied by the transfer of a $38-\mathrm{kb}$ plasmid. The mupirocin-resistant transconjugants were of two types: $c$. $70 \%$ of the colonies screened were resistant to mupirocin alone and contained a 38-kb plasmid. The second type of colonies were resistant to mupirocin and chloramphenicol and contained two plasmids of 38 and $4.4 \mathrm{~kb}$.

\section{Restriction endonuclease analysis (REA) of plasmids}

The 27-kb plasmids from the 1992 and 1997 isolates were digested with EcoRI restriction endonuclease and their restriction patterns were compared. The plasmids had similar EcoRI fragments. Their sizes were 11.0, 6.4, 4.0, 2.4, 2.1 and $1.2 \mathrm{~kb}$. EcoRI-digest of the 30-kb plasmid showed that it was also closely related to that of the $27-\mathrm{kb}$ plasmid. It yielded EcoRI fragments of sizes $11.0,7.0,6.4,2.4,2.1$ and $1.2 \mathrm{~kb}$. It carried an extra 7-kb EcoRI restriction fragment that was not present in the $27-\mathrm{kb}$ plasmid and lacked a 4-kb fragment that was present in the $27-\mathrm{kb}$ plasmid. The EcoRI-digest of the $15.2-\mathrm{kb}$ plasmid gave two fragments of 12 and $3.2 \mathrm{~kb}$, which were different from those of the $27-$ and $30-\mathrm{kb}$ plasmids.

\section{PFGE patterns}

All the 1992 and 1997 isolates were studied by PFGE of SmaI-digested DNA. They yielded well-resolved patterns of 12-14 fragments with sizes of $10-700 \mathrm{~kb}$ (Fig. 2). A single base mutation in the chromosomal DNA is sufficient to produce a difference of three fragments in its restriction pattern [11], and according to the criteria of Tenover et al. [20] for the interpretation of PFGE patterns, isolates with restriction patterns showing less than six fragments difference were considered to belong to a common major restriction type. On this basis, the MRSA isolates from 1992 were differentiated into two major types and two subtypes. The most common type was designated PFGE type 1, and was detected in $79(82 \%)$ of the 96 isolates (Table 4). The PFGE subtype 1a (5\%) differed from PFGE pattern 1 by one fragment. The

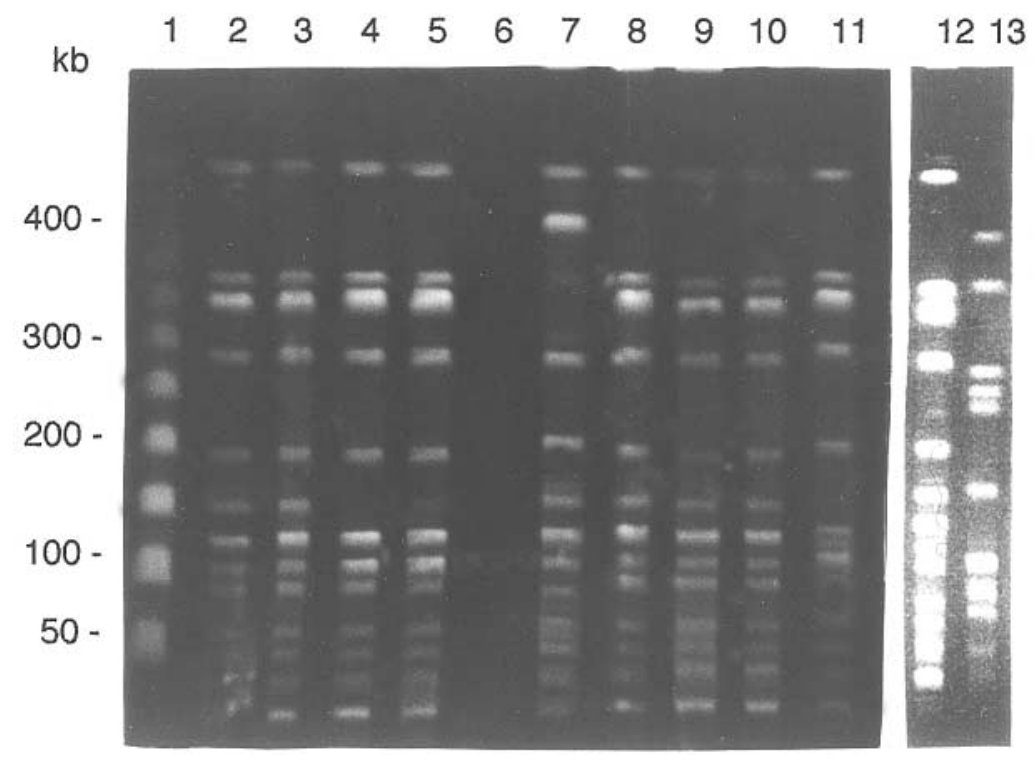

Fig. 2. FGE of isolates. Lane 1, $\lambda$ concatemer $(\mathrm{kb}) ; \mathbf{2}, \mathbf{3}, \mathbf{1 2}$, IBS73, IBS103, IBS123 isolated in 1992, PFGE pattern 1; 4, 5, IBS 36, IBS 147 isolated in 1992, PFGE pattern 1a; 7, IBS107, a 1992 isolate, PFGE pattern 1b; 8, 9, 10, IBS235, IBS247, IBS255 isolated in 1997, PFGE pattern 1; 11, IBS269, a 1997 isolate, PFGE pattern 1c; 13, IBS10, a 1992 isolate PFGE pattern 2. 
Table 4. Distribution of MRSA isolates by PFGE and plasmid analysis

\begin{tabular}{|c|c|c|c|}
\hline \multirow[b]{2}{*}{ PFGE type } & \multirow[b]{2}{*}{ Plasmids (kb) } & \multicolumn{2}{|c|}{ Number of isolates per year } \\
\hline & & 1992 & 1997 \\
\hline 1 & $\begin{array}{c}27,3.4,2.9 \\
30,3.4,2.9 \\
30,27,3.4,2.9 \\
27.3 .4 \\
15.2,3.4 \\
3.4,2.9 \\
3.4 \\
38,27,4.4,3.4,2.9 \\
27,4.4,3.4 \\
27,4.4,3.4,2.9 \\
38,27,4.4,3.4 \\
38,27,3.4 \\
27,3.4,2.5 \\
27,3.4,1.9\end{array}$ & $\begin{array}{r}51 \\
7 \\
4 \\
11 \\
2 \\
3 \\
1 \\
0 \\
0 \\
0 \\
0 \\
0 \\
0 \\
0\end{array}$ & $\begin{array}{r}0 \\
0 \\
0 \\
1 \\
0 \\
0 \\
0 \\
12 \\
5 \\
2 \\
1 \\
1 \\
2 \\
2\end{array}$ \\
\hline $1 \mathrm{a}$ & $\begin{array}{c}27,3.4,2.9 \\
30,27,3.4,2.9 \\
27,3.4\end{array}$ & $\begin{array}{l}3 \\
1 \\
1\end{array}$ & $\begin{array}{l}1 \\
0 \\
0\end{array}$ \\
\hline $1 b$ & $\begin{array}{c}15.2,3.4 \\
27,3.4,2.9 \\
30,27,3.4 \\
3.4\end{array}$ & $\begin{array}{l}6 \\
1 \\
1 \\
3\end{array}$ & $\begin{array}{l}0 \\
0 \\
0 \\
0\end{array}$ \\
\hline $1 \mathrm{c}$ & $\begin{array}{c}27,3.4 \\
38,27,3.4 \\
38,27,4.4,3.4\end{array}$ & $\begin{array}{l}0 \\
0 \\
0\end{array}$ & $\begin{array}{l}1 \\
3 \\
1\end{array}$ \\
\hline 2 & $15.2,3.4$ & 1 & 0 \\
\hline Total number of strains & 128 & 96 & 32 \\
\hline
\end{tabular}

PFGE subtype $1 \mathrm{~b}$ pattern was detected in 11 isolates $(12 \%)$, and differed from PFGE type 1 by four fragments. PFGE type 2 was found in only one isolate and differed from PFGE type 1 by nine fragments (Fig. 2). Almost all the 1997 MRSA isolates were of PFGE pattern $1(81 \%)$, or its subtypes $1 \mathrm{a}(3 \%)$ and $1 \mathrm{c}(16 \%)$, which also differed from the PFGE type 1 pattern by two fragments (Fig. 2).

\section{Hybridisation with mecA probe}

$m e c A$ DNA obtained by PCR amplification was labelled with digoxigenin-dUTP by the random priming method and used to probe chromosomal DNA of all 128 MRSA isolates obtained by PFGE. The aim was to determine whether the mecA DNA was located at different sites in the isolates. Results of DNA hybridisation revealed that the probe reacted with homologous DNA sequences in the same SmaI fragment (100-kb fragment) in all isolates (not shown).

\section{Discussion}

This study investigated the relatedness of MRSA strains isolated at a burns unit in Kuwait in 1992 and 1997. The isolates from both periods had similar resistance profiles with most of them resistant to aminoglycosides, macrolides, tetracycline, chloramphenicol, trimethoprim, ciprofloxacin, heavy metals and the nucleic acid-binding (NAB) compounds, propami- dine isethionate and ethidium bromide, similar to resistance profiles of MRSA isolated in other centres [21].

Although they differed in the number of plasmids that they harboured, the majority of the isolates harboured a $27-\mathrm{kb}$ plasmid that encoded resistance to propamidine isethionate, ethidium bromide, cadmium acetate and mercuric chloride. The $27-\mathrm{kb}$ plasmids in isolates from both years had identical EcoRI restriction patterns, indicating that they were the same or that the same plasmid had spread among unrelated MRSA strains. Plasmids encoding resistance to heavy metals and NAB compounds have also been reported in MRSA from Asia, England and Scotland [3]. In addition to the 27$\mathrm{kb}$ plasmids, some of the 1997 isolates contained a 38$\mathrm{kb}$ plasmid encoding high-level mupirocin resistance.

The relatedness of the MRSA isolates from both years was studied further by PFGE and DNA hybridisation with the mecA probe. The detection of the mecA DNA in the same Sma I fragment in all the isolates suggested that the MRSA isolates studied had a common origin or that the mecA gene was site-specific, being inserted in the same site in unrelated strains. Results of PFGE demonstrating that the majority of the isolates from the two periods belonged to PFGE pattern 1 confirmed the results of $m e c A$ probing and plasmid analysis indicating that a single clone of MRSA has persisted in the burn unit for over 5 years. It has been shown from other studies that some MRSA clones were capable of 
persisting for long periods in hospitals [6], and that they can spread over wide geographic areas [7]. A possible explanation for this persistence could be the presence of a reservoir of infection, such as contaminated environment or colonised patients, that allows this particular MRSA clone to spread among patients. A virulence-related property such as increased adherence resulting in colonisation and infection may also exist in this clone. Chronic carriage of MRSA by hospital staff can also contribute to endemicity [22], however, this has not been established in the burns unit. Nevertheless, other work has revealed that MRSA carriage by hospital staff contributed to the transmission of MRSA in hospitals [22].

Besides the dominant PFGE type found in 1992 and 1997, PFGE subtype 1a and b were also detected. These were variants of the prevalent PFGE pattern 1, as they differed by fewer than six DNA fragments $[11,20]$. One PFGE pattern and one subtype detected less frequently in 1992 disappeared in 1997. The presence in 1997 of only PFGE pattern 1 or its subtypes indicated that no new clones have established successfully in the unit. Therefore, implementation of infection control measures may help in reducing further transmission of this MRSA clone within the burns unit.

In conclusion, this study has demonstrated the persistence of a multiresistant MRSA clone in the burns unit for 5 years. This finding calls for urgent implementation of measures to reduce or eliminate the persistant clone. Restrictive use of antibiotics and strict isolation measures contributed to the low frequency and to the eradication of MRSA in some institutions $[22,23]$. Surveillance of medical staff for the carriage of MRSA may be helpful in detecting staff carriage and subsequent control of MRSA spread in the burns unit.

This project was supported in part by NH and MRC grants to W.B.G and partly by grant M1091 to E.E.U. from Kuwait University Research Administration.

\section{References}

1. Boyce JM. Methicillin-resistant Staphylococcus aureus: a continuing infection control challenge. Eur J Clin Microbiol Infect Dis 1994; 13: 45-49.

2. Ayliffe GAJ. The progressive intercontinental spread of methicillin-resistant Staphylococcus aureus. Clin Infect Dis 1997; 24 Suppl 1: S74-S79.

3. Grubb WB. Genetics of MRSA. Rev Med Microbiol 1998; 9: $153-162$.

4. Lyon BR. Skurray R. Antimicrobial resistance of Staphylococcus aureus: genetic basis. Microbiol Rev 1987; 51: 88-134.

5. Carbon C. Costs of treating infections caused by methicillinresistant staphylococci and vancomycin-resistant enterococci. J Antimicrob Chemother 1999; 44 (Topic A): 31-36.
6. Sabria-Leal M, Morthland VH, Pedro-Botet ML et al. Molecular epidemiology of local outbreaks of methicillinresistant Staphylococcus aureus (MRSA). The need for several methods. Eur J Epidemiol 1994; 10: 325-330.

7. Mato R, Santos Sanches I, Venditti M et al. Spread of the multiresistant Iberian clone of methicillin-resistant Staphylococcus aureus (MRSA) to Italy and Scotland. Microb Drug Resist 1998; 4: 107-112.

8. Gillespie MT, May JW, Skurray RA. Antibiotic resistance in Staphylococcus aureus isolated at an Australian hospital between 1946 and 1981. J Med Microbiol 1985; 19: 137-147.

9. Liu PY-F, Shi Z-Y, Lau Y-J et al. Use of restriction endonuclease analysis of plasmids and pulsed-field gel electrophoresis to investigate outbreaks of methicillin-resistant Staphylococcus aureus infection. Clin Infect Dis 1996; 22: 86-90.

10. Wei M-Q, Wang F, Grubb WB. Use of countour-clamped homogeneous electric field (CHEF) electrophoresis to type methicillin-resistant Staphylococcus aureus. J Med Microbiol 1992; 36: 172-176.

11. Struelens MJ, Deplano A, Godard, C, Maes N, Serruys E. Epidemiologic typing and delineation of genetic relatedness of methicillin-resistant Staphylococcus aureus by macrorestriction analysis of genomic DNA by using pulsed-field gel electrophoresis. J Clin Microbiol 1992; 30: 2599-2605.

12. Monzon-Moreno C, Aubert S, Morvan A, El Solh N. Usefulness of three probes in typing isolates of methicillinresistant Staphylococcus aureus (MRSA). J Med Microbiol 1991; 35: 80-88.

13. Yoshida T, Kondo N, Abu Hanifah Y, Hiramatsu K. Combined use of ribotyping, PFGE typing and IS431 typing in the discrimination of nosocomial strains of methicillin-resistant Staphylococcus aureus. Microbiol Immunol 1997; 41: 687-695.

14. Udo EE, Farook VS, Mokadas EM, Jacob LE, Sanyal SC. Molecular fingerprinting of mupirocin-resistant methicillinresistant Staphylococcus aureus from a burn unit. Int $J$ Infect Dis 1999; 3: 82-87.

15. Townsend DE, Ashdown N, Greed LC, Grubb WB. Transposition of gentamicin resistance to staphylococcal plasmids encoding resistance to cationic agents. J Antimicrob Chemother 1984; 14: 115-124.

16. Townsend DE, Ashdown N, Bolton S, Grubb WB. The use of cetyltrimethylammonium bromide for the rapid isolation from Staphylococcus aureus of relaxable and non-relaxable plasmid DNA suitable for in vitro manipulation. Lett Appl Microbiol 1985; 1: 87-94.

17. Udo EE, Grubb WB. Transfer of resistance determinants from a multi-resistant Staphylococcus aureus isolate. J Med Microbiol 1991; 35: 72-79.

18. Farrell DJ. The reliability of Microscan ${ }^{\mathrm{TM}}$ conventional and rapid panels to identify Staphylococcus aureus and detect methicillin resistance: an evaluation using the tube coagulase and mecA PCR. Pathology 1997; 29: 406-410.

19. Sambrook J, Fritsch EF, Maniatis T. Molecular cloning, a laboratory manual, 2nd edn. Cold Spring Harbor, NY, Cold Spring Harbor Laboratory Press 1989.

20. Tenover FC, Arbeit RD, Goering RV et al. Interpreting chromosomal DNA restriction patterns produced by pulsedfield gel electrophoresis: criteria for bacterial strain typing. J Clin Microbiol 1995; 33: 2233-2239.

21. Van der Auwera P, Godard C, Denis C, De Maeyer S, Vanhoof R. In vitro activities of new antimicrobial agents against multiresistant Staphylococcus aureus isolated from septicemia patients during a Belgian national survey from 1983 to 1985 . Antimicrob Agents Chemother 1990; 34: 2260-2262.

22. de Neeling AJ, van Leeuwen WJ, Schouls LM et al. Resistance of staphylococci in the Netherlands: surveillance by an electronic network during 1989-1995. J Antimicrob Chemother 1998; 41: 93-101.

23. Tambic A, Power EGM, Talsania H, Anthony RM, French GL. Analysis of an outbreak of non-phage-typeable methicilinresistant Staphylococcus aureus by using a randomly amplified polymorphic DNA assay. $J$ Clin Microbiol 1997; 35: 3092-3097. 